\title{
Personnel selection with grey relational analysis
}

\author{
Nilsen Kundakcı*
}

Assist. Prof. Dr., Pamukkale University, Department of Business Administration, Denizli, Turkey

\begin{tabular}{l}
\hline C H R O N I C L E \\
\hline Article history: \\
Received October 28, 2015 \\
Received in revised format \\
November 28, 2015 \\
Accepted March 22, 2016 \\
Available online \\
March 24, 2016 \\
\hline Keywords: \\
Personnel Selection \\
Grey Relational Analysis \\
MCDM
\end{tabular}

\section{A B S T R A C T}

\begin{abstract}
Selection of the qualified and the most appropriate employee plays crucial role for the success of the businesses. The selection process is complex and contains both subjective and objective criteria to be considered. For this reason, in this paper, Grey Relational Analysis (GRA) is proposed for employee selection. To illustrate the applicability of the proposed method, the most appropriate software engineer is selected for a technology firm. By this way, a scientific multi criteria decision making (MCDM) method is proposed to the firm that determines the best candidate intuitively with traditional methods.
\end{abstract}

\section{Introduction}

Employee selection is the process of choosing the most appropriate people among the candidates who apply for a job in a firm. In today's competitive environment, selection of the best and the most qualified employee plays a key success factor for the firms. Because performance, knowledge and skills of the employee affect the future survival of firms. Therefore, human resources (HR) departments give more importance to personnel selection process and try to use more scientific methods. On the other hand, firms have different recruiting procedures. Some firms use costly and long time consuming processes for selecting the most appropriate personnel, while others complete the recruitment process faster and less costly using traditional methods. In the literature, various methods are proposed for personnel selection to aid the firms in this important decision making process. Most of these methods are multi criteria decision making methods like Simple Additive Weighting (SAW), Analytic Hierarchy Process (AHP), Analytic Network Process (ANP), TOPSIS (Technique for Order Preference by Similarity to Ideal Solution), PROMETHEE (Preference Ranking Organization Method for Enrichment Evaluations), MULTI-MOORA (Multi-Objective Optimization on the basis of Ratio Analysis), VIKOR (Vise Kriterijumska Optimizacija I Kompromisno Resenje), DEMATEL (Decision Making Trial and Evaluation Laboratory) and Grey Relational Analysis (GRA). At the same time, extended

* Corresponding author. Tel: +9025826926 99, Fax:+90 2582962626

E-mail address: nkarakasoglu@pau.edu.tr (N. Kundakc1) 
fuzzy version of these methods are used to solve personnel selection problems. Also other methods like data mining, game theory, multi objective programming and Data Envelopment Analysis (DEA) are proposed for personnel selection. These methods are summarized on Table 1.

In this paper, Grey Relational Analysis is proposed for personnel selection problem and a real life application of technology firm is given in order to show the applicability of the method. This paper is organized as follows: In the second section, GRA method is introduced and a comprehensive literature review is given and also steps of the method are summarized. Next, application of personnel selection in a technology firm is given in the third section. Finally, obtained results are discussed and suggestions for future research are offered in the fourth section.

Table 1

Methods proposed for personnel selection

\begin{tabular}{ll}
\hline Authors & Method \\
\hline $\begin{array}{l}\text { Liang and Wang (1994), Tsao and Chu (2001), } \\
\text { Dursun and Karsak (2010) }\end{array}$ & Fuzzy MCDM \\
$\begin{array}{l}\text { Chen (2000), Saghafian and Hejazi (2005), Nasab and } \\
\text { Malkhalifeh (2010), Kelemenis and Askounis (2010), Boran et } \\
\text { al. (2011), Fathi et al. (2011) }\end{array}$ & \\
Karsak (2000) & A Fuzzy Multiple Objective Programming \\
Chen and Cheng (2005) & Fuzzy Group Decision Support System \\
Chien and Chen (2008) & Data Mining \\
Güngör et al. (2009) & Fuzzy AHP \\
Dereli et al. (2010) & Fuzzy PROMETHEE \\
Afshari et al. (2010) & SAW \\
Dağdeviren (2010) & ANP and TOPSIS \\
Lin (2010) & Fuzzy AHP and Fuzzy DEA \\
Zhang and Liu (2011) & Fuzzy Grey Relational Analysis \\
Baležentis et al. (2012) & MULTI-MOORA \\
El-Santawy (2012) & VIKOR \\
Aksakal et al. (2013) & DEMATEL and TOPSIS \\
Kabak (2013) & Fuzzy DEMATEL and ANP \\
Kalugina and Shvydun (2014) & A New Mathematical Approach and a Computer Tool \\
Zolfani and Banihashemi (2014) & Game Theory and MCDM approaches \\
\hline Liu et al. (2015), Alguliyev et al. (2015) & Fuzzy VIKOR \\
\hline
\end{tabular}

\section{Grey Relational Analysis}

Grey method was firstly proposed by Deng (1989) for the solution of the problems which have uncertainty. In this method, "grey" means insufficient data or information in decision making process. Grey relational analysis (GRA), is based on grey system theory and it has been widely implemented to solve decision making problems with qualitative and quantitative data under complex criteria. The calculations of GRA method are simple and easy to understand. For this reason, it can be easily used in decision making process of businesses and it was applied to many areas by different authors in the literature. For instance, Huang and Huang (1996) proposed an integrated approach based on fuzzy and grey model and applied it to the prediction control problems. Chang and Lin (1999) identified the factors affecting energy-induced $\mathrm{CO}_{2}$ emission changes in Taiwan by using GRA. Wu (2002) proposed to use GRA in multi-criteria decision making problems. Lin et al. (2002) applied GRA and fuzzy Taguchi method to optimize the electrical discharge machining process. Chang et al. (2003) used GRA to develop an accurate model for Decathlon. Fung (2003) optimized the parameters of injection molding process by using GRA. Tsai et al. (2003) developed vender evaluation model with GRA. Lin (2004) used GRA and Taguchi method for the optimization of turning operations. Kao and Hocheng (2003) optimized the electrochemical polishing of stainless steel performance by the help of GRA. Wen (2004) solved the probability of gas breakdown and the suitable location of VAR compensator in feeding problems by using GRA. Yang and Chen (2006) integrated AHP and GRA methods for supplier selection. Tosun (2006) determined the optimum performance parameters for drilling process with 
GRA. Chiang and Chang (2006) optimized the performance of wire electric discharge machining process by using GRA. Moran et al. (2006) evaluated different biomass fuels in small boilers with GRA. Chan and Tong (2007) proposed to use GRA for material selection of manufacturing firms. Zeng et al. (2007) selected the most appropriate wastewater treatment alternative with AHP and GRA methods. Kuo et al. (2008) proposed GRA and DEA to solve selection of dispatching rules and facility layout problems. Lu et al. (2008) used GRA for determining the factors in transportation system and evaluated the energy consumption of motor vehicular. Huang et al. (2008) combined GRA and genetic algorithm to estimate software effort. Çaydaş and Hasçalık (2008) used GRA method to optimize laser cutting parameters. Yang et al. (2009) combined AHP and GRA methods to develop land suitability evaluation model. Tzeng et al. (2009) optimized the performance of turning operations with Taguchi and GRA methods. Chen and Chen (2010) applied AHP, TOPSIS and GRA methods to evaluate maintenance performance of the semiconductor factories. Tseng (2010) evaluated environmental knowledge management capacity with the help of GRA and linguistic preferences. Sarucan et al. (2011) integrated AHP and GRA to evaluate renewable electricity generation technologies. Wei (2011) proposed GRA for 2-tuple linguistic MCDM problems with incomplete weight information. Xu et al. (2011) evaluated the performance of coal fired power plants with the combination of AHP and GRA methods. Hasani et al. (2012) determined the optimum process parameters for open-end spinning yarns with the help of GRA and Taguchi method. Özçelik and Öztürk (2014) used GRA to evaluate the performance of banks in Turkey. Birgün and Güngör (2014) used AHP and GRA for call center site selection. Rajesh and Ravi (2015) applied GRA for supplier selection. Pandey and Panda (2015) optimized the quality characteristics of bone drilling with GRA. Li et al. (2015) proposed impoved GRA for panel data clustering. Wang et al. (2015) used GRA and AHP methods for the biomass briquette fuel system optimization. Hashemi et al. (2015) selected green suppler with ANP and GRA. Das et al. (2016) proposed to used GRA for optimizing the fabrication process of a metal matrix composites. Tripathy and Tripathy (2016) optimized the parameters of machining process in powder mixed electro-discharge machining with GRA and TOPSIS methods.

The steps of the Grey Relational Analysis can be summarized as follows:

Step 1. Obtaining data set and forming the decision matrix:

Decision matrix $X_{i}$ is formed assuming that there are $m$ alternatives and $n$ criteria.

$$
X_{i}=\left[\begin{array}{cccc}
x_{1}(1) & x_{1}(2) & \ldots & x_{1}(n) \\
x_{2}(1) & x_{2}(2) & \ldots & x_{2}(n) \\
\vdots & \vdots & \ddots & \vdots \\
x_{m}(1) & x_{m}(2) & \cdots & x_{m}(n)
\end{array}\right] \quad i=1,2, \ldots, m \quad j=1,2, \ldots, n
$$

Here $x_{i}$ indicates the alternatives and $x_{i}(j)$ is the value of $i^{\text {th }}$ alternative with respect to $j^{\text {th }}$ criterion.

Step 2. Normalization of the decision matrix:

Different normalization formulas are used for the type of the criteria. For benefit (maximization) criteria normalization formula is given in Eq. (2):

$$
x_{i}^{*}=\frac{x_{i}(j)-\min _{j} x_{i}(j)}{\max _{j} x_{i}(j)-\min _{j} x_{i}(j)}
$$

Normalization formula for cost (minimization) criteria is like in Eq. (3):

$$
x_{i}^{*}=\frac{\max _{j} x_{i}(j)-x_{i}(j)}{\max _{j} x_{i}(j)-\min _{j} x_{i}(j)}
$$


For nominal-is-best, if the target value is $x_{0 b}(j)$ and $\max _{j} x_{i}(j) \geq x_{0 b}(j) \geq \min _{j} x_{i}(j)$, normalization formula is given in Eq. (4):

$$
x_{i}^{*}=\frac{\left|x_{i}(j)-x_{0 b}(j)\right|}{\max _{j} x_{i}(j)-x_{0 b}(j)}
$$

Later, normalized decision matrix is formed as seen in Eq. (5)

$$
X_{i}^{*}=\left[\begin{array}{cccc}
x_{1}^{*}(1) & x_{1}^{*}(2) & \ldots & x_{1}^{*}(n) \\
x_{2}^{*}(1) & x_{2}^{*}(2) & \ldots & x_{2}^{*}(n) \\
\vdots & \vdots & \ddots & \vdots \\
x_{m}^{*}(1) & x_{m}^{*}(2) & \cdots & x_{m}^{*}(n)
\end{array}\right]
$$

Step 3. Generation of the reference series.

The reference value of the $j^{\text {th }}$ criterion $x_{0}^{*}(j)$ is determined by taking the maximum normalized value of each criterion with the help of Eq. (6)

$$
\begin{aligned}
& x_{0}^{*}(j)=\max _{i=1}^{m}\left\{x_{i}(j)\right\} \\
& x_{0}^{*}(j)=\left\{x_{0}^{*}(1), x_{0}^{*}(2), \ldots, x_{0}^{*}(n)\right\}
\end{aligned}
$$

Step 4. Forming the difference matrix:

$\Delta_{0 i}(j)$ distance is calculated. It indicates the absolute value of difference between normalized values $\left(x_{0}^{*}\right)$ and reference values $\left(x_{0}^{*}\right)$ at the $j^{\text {th }}$ point.

$$
\begin{aligned}
& \Delta_{0 i}(j)=\left|x_{0}^{*}(j)-x_{i}^{*}(j)\right| \\
& \Delta_{0 i}(j)=\left|x_{0}^{*}(j)-x_{i}^{*}(j)\right|=\left[\begin{array}{cccc}
\Delta_{01}(1) & \Delta_{01}(2) & \ldots & \Delta_{01}(n) \\
\Delta_{02}(1) & \Delta_{02}(2) & \ldots & \Delta_{02}(n) \\
\vdots & \vdots & \ddots & \vdots \\
\Delta_{0 m}(1) & \Delta_{0 m}(2) & \cdots & \Delta_{0 m}(n)
\end{array}\right]
\end{aligned}
$$

Step 5. Computing grey relational coefficient:

$$
\gamma_{0 i}(j)=\frac{\Delta_{\min }+\zeta \Delta_{\max }}{\Delta_{0 i}(j)+\zeta \Delta_{\max }}
$$

Here, $\Delta_{\max }=\max _{i} \max _{j} \Delta_{0 i}(j), \Delta_{\min }=\min _{i} \min _{j} \Delta_{0 i}(j)$ and $\zeta \in[0,1] . \zeta$ is distinguishing coefficient and usually taken as 0.5 by the decision makers in the literature as this value offers good stability and distinguishing effects (Özçelik \& Öztürk, 2014).

Step 6. Computing the degree of grey coefficient $\Gamma_{0 i}$. If the criteria weights equal to each other Eq. (11) is used:

$$
\Gamma_{0 i}=\frac{1}{n} \sum_{j=1}^{n} \gamma_{0 i}(j)
$$

If the criteria have different weights, grey coefficient $\Gamma_{0 i}$ can be calculated via Eq. (12). 


$$
\begin{aligned}
& \Gamma_{0 i}=\sum_{j=1}^{n}\left[w(j) \cdot \gamma_{0 i}(j)\right] \\
& \sum_{j=1}^{n} w(j)=1
\end{aligned}
$$

Here $w(j)$ indicates the weight of the $j^{\text {th }}$ criterion.

$\Gamma_{0 i}$ grey relational grade shows the similarity of alternative and reference series (Özçelik \& Öztürk, 2014).

Step 7. Determining the overall performance of alternatives and selecting the best one:

Overall performance of alternatives under all criteria are determined according to the grey relational grade. The alternative with the highest grade of relation will be identified as the best alternative.

\section{Application}

In this section, Grey Relational Analysis is applied to a personnel selection problem of a technology firm. This technology firm located in İstanbul, Turkey and wanted to hire a software engineer. For this reason, they posted a job announcement. Total 607 candidates applied for this position. From these candidates 153 candidates were found appropriate in pre-assessment and then telephone interview was made with 83 candidate whose qualifications are adequate for the position. Then face to face interviews were made with 37 candidates in both HR and Information Technology (IT) departments. Finally HR department chose 8 candidates and applied them personality inventory. According to the results of this personality inventory they will make a final decision to determine the most appropriate candidate for this position. Personality inventory that has applied to 8 candidates based on twelve core competencies seen in Table 2. These core competencies are selected as the personnel selection criteria in GRA.

Table 2

Personnel selection criteria

\begin{tabular}{lclc}
\hline $\mathbf{C}_{\mathbf{1}}$ & Analytical thinking and problem solving & $\mathbf{C}_{7}$ & Teamwork and collaboration \\
$\mathbf{C}_{\mathbf{2}}$ & Results orientation & $\mathbf{C}_{\mathbf{8}}$ & Conflict resolution \\
$\mathbf{C}_{\mathbf{3}}$ & Initiative & $\mathbf{C}_{\mathbf{9}}$ & Change orientation \\
$\mathbf{C}_{\mathbf{4}}$ & Decision making & $\mathbf{C}_{\mathbf{1 0}}$ & Planning and organizing \\
$\mathbf{C}_{5}$ & Ability to work independently & $\mathbf{C}_{11}$ & Stress management \\
$\mathbf{C}_{\mathbf{6}}$ & Influencing and persuading & $\mathbf{C}_{\mathbf{1 2}}$ & Openness to learning and development \\
\hline
\end{tabular}

First, based on the result of the personality inventory, decision matrix with linguistic variables formed like in Table 3.

Table 3

\begin{tabular}{|c|c|c|c|c|c|c|c|c|c|c|c|c|}
\hline \multirow[b]{2}{*}{ Alternatives } & \multicolumn{12}{|c|}{ Criteria } \\
\hline & $\mathrm{C}_{1}$ & $\mathrm{C}_{2}$ & $\mathrm{C}_{3}$ & $\mathrm{C}_{4}$ & $\mathrm{C}_{5}$ & $\mathrm{C}_{6}$ & $\mathrm{C}_{7}$ & $\mathrm{C}_{8}$ & $\mathrm{C}_{9}$ & $\mathrm{C}_{10}$ & $\mathrm{C}_{11}$ & $\mathrm{C}_{12}$ \\
\hline $\mathrm{A}_{1}$ & $\mathrm{H}$ & $\mathrm{M}$ & $\mathrm{M}$ & $\mathrm{L}$ & $\mathrm{M}$ & $\mathrm{L}$ & $\mathrm{M}$ & $\mathrm{L}$ & $\mathrm{VH}$ & $\mathrm{M}$ & $\mathrm{H}$ & $\mathrm{M}$ \\
\hline $\mathrm{A}_{2}$ & M & $\mathrm{H}$ & $\mathrm{H}$ & M & VH & M & M & M & $\mathrm{L}$ & $\mathrm{H}$ & M & M \\
\hline $\mathrm{A}_{3}$ & $\mathrm{H}$ & $\mathrm{H}$ & M & $\mathrm{H}$ & $\mathrm{H}$ & $\mathrm{H}$ & M & $\mathrm{H}$ & $\mathrm{H}$ & $\mathrm{L}$ & $\mathrm{H}$ & $\mathrm{H}$ \\
\hline $\mathrm{A}_{4}$ & M & M & M & M & M & M & $\mathrm{M}$ & M & $\mathrm{H}$ & $\mathrm{H}$ & $\mathrm{M}$ & M \\
\hline $\mathrm{A}_{5}$ & $\mathrm{H}$ & M & $\mathrm{H}$ & M & M & $\mathrm{H}$ & VH & M & VH & $\mathrm{H}$ & VH & $\mathrm{H}$ \\
\hline $\mathrm{A}_{6}$ & $\mathrm{~L}$ & M & M & $\mathrm{L}$ & $\mathrm{H}$ & $\mathrm{M}$ & $\mathrm{M}$ & $\mathrm{H}$ & $\mathrm{H}$ & $\mathrm{H}$ & $\mathrm{M}$ & M \\
\hline $\mathrm{A}_{7}$ & $\mathrm{H}$ & $\mathrm{H}$ & $\mathrm{L}$ & $\mathrm{H}$ & M & VH & $\mathrm{H}$ & $\mathrm{H}$ & $\mathrm{H}$ & $\mathrm{M}$ & M & $\mathrm{H}$ \\
\hline $\mathrm{A}_{8}$ & M & $\mathrm{H}$ & $\mathrm{L}$ & $\mathrm{H}$ & $\mathrm{H}$ & M & $\mathrm{H}$ & $\mathrm{H}$ & $\mathrm{H}$ & $\mathrm{VH}$ & $\mathrm{H}$ & $\mathrm{VH}$ \\
\hline
\end{tabular}

Decision matrix with linguistic variables

Later this matrix with linguistic variables is converted to decision matrix with numerical values by using the scale at Table 4. This scale is used by the HR department of the company. They determined 
the linguistic variables and their equivalent numerical scale and used in their personality inventory studies. Finally decision matrix with numerical values is obtained like in Table 5.

\section{Table 4}

Scale

\begin{tabular}{lc}
\hline Linguistic Variables & Equivalent Numerical Scale \\
\hline Very Low (VL) & 1 \\
Low (L) & 2 \\
Medium (M) & 3 \\
High (H) & 4 \\
Very High $(\mathrm{VH})$ & 5 \\
\hline
\end{tabular}

Table 5

Decision matrix

\begin{tabular}{cccccccccccccc}
\hline & \multicolumn{10}{c}{ Criteria } \\
\hline Alternatives & $\mathrm{C}_{1}$ & $\mathrm{C}_{2}$ & $\mathrm{C}_{3}$ & $\mathrm{C}_{4}$ & $\mathrm{C}_{5}$ & $\mathrm{C}_{6}$ & $\mathrm{C}_{7}$ & $\mathrm{C}_{8}$ & $\mathrm{C}_{9}$ & $\mathrm{C}_{10}$ & $\mathrm{C}_{11}$ & $\mathrm{C}_{12}$ \\
\hline $\mathrm{A}_{1}$ & 4 & 3 & 3 & 4 & 3 & 2 & 3 & 2 & 5 & 3 & 4 & 3 \\
$\mathrm{~A}_{2}$ & 3 & 4 & 4 & 3 & 5 & 3 & 3 & 3 & 2 & 4 & 3 & 3 \\
$\mathrm{~A}_{3}$ & 4 & 4 & 3 & 4 & 4 & 4 & 3 & 4 & 4 & 2 & 4 & 4 \\
$\mathrm{~A}_{4}$ & 3 & 3 & 3 & 3 & 3 & 3 & 3 & 3 & 4 & 4 & 3 & 3 \\
$\mathrm{~A}_{5}$ & 4 & 3 & 4 & 3 & 3 & 4 & 5 & 3 & 5 & 4 & 5 & 4 \\
$\mathrm{~A}_{6}$ & 2 & 3 & 3 & 2 & 4 & 3 & 3 & 4 & 4 & 4 & 3 & 3 \\
$\mathrm{~A}_{7}$ & 4 & 4 & 2 & 4 & 3 & 5 & 4 & 4 & 4 & 3 & 3 & 4 \\
$\mathrm{~A}_{8}$ & 3 & 4 & 2 & 4 & 4 & 3 & 4 & 4 & 4 & 5 & 4 & 5 \\
\hline
\end{tabular}

After forming the decision matrix, it is normalized by using Eq. (2). By this way, normalized decision matrix is formed like in Table 6. Then, reference values are determined by taking the maximum normalized value of each criterion with the help of Eq. (6).

Table 6

Normalized decision matrix and reference series

\begin{tabular}{ccccccccccccc}
\hline & & \multicolumn{1}{c}{ Criteria } \\
\hline Alternatives & $\mathrm{C}_{1}$ & $\mathrm{C}_{2}$ & $\mathrm{C}_{3}$ & $\mathrm{C}_{4}$ & $\mathrm{C}_{5}$ & $\mathrm{C}_{6}$ & $\mathrm{C}_{7}$ & $\mathrm{C}_{8}$ & $\mathrm{C}_{9}$ & $\mathrm{C}_{10}$ & $\mathrm{C}_{11}$ & $\mathrm{C}_{12}$ \\
\hline $\mathrm{A}_{1}$ & 1.00 & 0.00 & 0.50 & 1.00 & 0.00 & 0.00 & 0.00 & 0.00 & 1.00 & 0.33 & 0.50 & 0.00 \\
$\mathrm{~A}_{2}$ & 0.50 & 1.00 & 1.00 & 0.50 & 1.00 & 0.33 & 0.00 & 0.50 & 0.00 & 0.67 & 0.00 & 0.00 \\
$\mathrm{~A}_{3}$ & 1.00 & 1.00 & 0.50 & 1.00 & 0.50 & 0.67 & 0.00 & 1.00 & 0.67 & 0.00 & 0.50 & 0.50 \\
$\mathrm{~A}_{4}$ & 0.50 & 0.00 & 0.50 & 0.50 & 0.00 & 0.33 & 0.00 & 0.50 & 0.67 & 0.67 & 0.00 & 0.00 \\
$\mathrm{~A}_{5}$ & 1.00 & 0.00 & 1.00 & 0.50 & 0.00 & 0.67 & 1.00 & 0.50 & 1.00 & 0.67 & 1.00 & 0.50 \\
$\mathrm{~A}_{6}$ & 0.00 & 0.00 & 0.50 & 0.00 & 0.50 & 0.33 & 0.00 & 1.00 & 0.67 & 0.67 & 0.00 & 0.00 \\
$\mathrm{~A}_{7}$ & 1.00 & 1.00 & 0.00 & 1.00 & 0.00 & 1.00 & 0.50 & 1.00 & 0.67 & 0.33 & 0.00 & 0.50 \\
$\mathrm{~A}_{8}$ & 0.50 & 1.00 & 0.00 & 1.00 & 0.50 & 0.33 & 0.50 & 1.00 & 0.67 & 1.00 & 0.50 & 1.00 \\
\hline Reference & 1.00 & 1.00 & 1.00 & 1.00 & 1.00 & 1.00 & 1.00 & 1.00 & 1.00 & 1.00 & 1.00 & 1.00 \\
\hline
\end{tabular}

Later, difference matrix is formed by using Eq. (8) as seen in Table 7. Then, grey relational coefficients are computed via Eq. (10) like in Table 8.

Table 7

Difference matrix

\begin{tabular}{ccccccccccccc}
\hline & \multicolumn{10}{c}{ Criteria } \\
\hline Alternatives & $\mathrm{C}_{1}$ & $\mathrm{C}_{2}$ & $\mathrm{C}_{3}$ & $\mathrm{C}_{4}$ & $\mathrm{C}_{5}$ & $\mathrm{C}_{6}$ & $\mathrm{C}_{7}$ & $\mathrm{C}_{8}$ & $\mathrm{C}_{9}$ & $\mathrm{C}_{10}$ & $\mathrm{C}_{11}$ & $\mathrm{C}_{12}$ \\
\hline $\mathrm{A}_{1}$ & 0.00 & 1.00 & 0.50 & 0.00 & 1.00 & 1.00 & 1.00 & 1.00 & 0.00 & 0.67 & 0.50 & 1.00 \\
$\mathrm{~A}_{2}$ & 0.50 & 0.00 & 0.00 & 0.50 & 0.00 & 0.67 & 1.00 & 0.50 & 1.00 & 0.33 & 1.00 & 1.00 \\
$\mathrm{~A}_{3}$ & 0.00 & 0.00 & 0.50 & 0.00 & 0.50 & 0.33 & 1.00 & 0.00 & 0.33 & 1.00 & 0.50 & 0.50 \\
$\mathrm{~A}_{4}$ & 0.50 & 1.00 & 0.50 & 0.50 & 1.00 & 0.67 & 1.00 & 0.50 & 0.33 & 0.33 & 1.00 & 1.00 \\
$\mathrm{~A}_{5}$ & 0.00 & 1.00 & 0.00 & 0.50 & 1.00 & 0.33 & 0.00 & 0.50 & 0.00 & 0.33 & 0.00 & 0.50 \\
$\mathrm{~A}_{6}$ & 1.00 & 1.00 & 0.50 & 1.00 & 0.50 & 0.67 & 1.00 & 0.00 & 0.33 & 0.33 & 1.00 & 1.00 \\
$\mathrm{~A}_{7}$ & 0.00 & 0.00 & 1.00 & 0.00 & 1.00 & 0.00 & 0.50 & 0.00 & 0.33 & 0.67 & 1.00 & 0.50 \\
$\mathrm{~A}_{8}$ & 0.50 & 0.00 & 1.00 & 0.00 & 0.50 & 0.67 & 0.50 & 0.00 & 0.33 & 0.00 & 0.50 & 0.00 \\
\hline
\end{tabular}


Table 8

Grey relational coefficients

\begin{tabular}{ccccccccccccc}
\hline & \multicolumn{10}{c}{ Criteria } \\
\hline Alternatives & $\mathrm{C}_{1}$ & $\mathrm{C}_{2}$ & $\mathrm{C}_{3}$ & $\mathrm{C}_{4}$ & $\mathrm{C}_{5}$ & $\mathrm{C}_{6}$ & $\mathrm{C}_{7}$ & $\mathrm{C}_{8}$ & $\mathrm{C}_{9}$ & $\mathrm{C}_{10}$ & $\mathrm{C}_{11}$ & $\mathrm{C}_{12}$ \\
\hline $\mathrm{A}_{1}$ & 1.00 & 0.33 & 0.50 & 1.00 & 0.33 & 0.33 & 0.33 & 0.33 & 1.00 & 0.43 & 0.50 & 0.33 \\
$\mathrm{~A}_{2}$ & 0.50 & 1.00 & 1.00 & 0.50 & 1.00 & 0.43 & 0.33 & 0.50 & 0.33 & 0.60 & 0.33 & 0.33 \\
$\mathrm{~A}_{3}$ & 1.00 & 1.00 & 0.50 & 1.00 & 0.50 & 0.60 & 0.33 & 1.00 & 0.60 & 0.33 & 0.50 & 0.50 \\
$\mathrm{~A}_{4}$ & 0.50 & 0.33 & 0.50 & 0.50 & 0.33 & 0.43 & 0.33 & 0.50 & 0.60 & 0.60 & 0.33 & 0.33 \\
$\mathrm{~A}_{5}$ & 1.00 & 0.33 & 1.00 & 0.50 & 0.33 & 0.60 & 1.00 & 0.50 & 1.00 & 0.60 & 1.00 & 0.50 \\
$\mathrm{~A}_{6}$ & 0.33 & 0.33 & 0.50 & 0.33 & 0.50 & 0.43 & 0.33 & 1.00 & 0.60 & 0.60 & 0.33 & 0.33 \\
$\mathrm{~A}_{7}$ & 1.00 & 1.00 & 0.33 & 1.00 & 0.33 & 1.00 & 0.50 & 1.00 & 0.60 & 0.43 & 0.33 & 0.50 \\
$\mathrm{~A}_{8}$ & 0.50 & 1.00 & 0.33 & 1.00 & 0.50 & 0.43 & 0.50 & 1.00 & 0.60 & 1.00 & 0.50 & 1.00 \\
\hline
\end{tabular}

In Table 9, weights of the criteria determined by the HR department of the company can be seen. These weights are determined by two experts from HR department and one Information Technology (IT) director. By considering these weights, grey relational grades are computed with the help of Eq. (12) and these values can be seen in the last column of Table 9.

Table 9

Grey relational grades

\begin{tabular}{cccccccccccccc}
\hline & \multicolumn{10}{c}{ Criteria } \\
\hline Weights & 0.10 & 0.10 & 0.07 & 0.08 & 0.09 & 0.07 & 0.09 & 0.07 & 0.07 & 0.10 & 0.07 & 0.09 \\
\hline Alternatives & $\mathrm{C}_{1}$ & $\mathrm{C}_{2}$ & $\mathrm{C}_{3}$ & $\mathrm{C}_{4}$ & $\mathrm{C}_{5}$ & $\mathrm{C}_{6}$ & $\mathrm{C}_{7}$ & $\mathrm{C}_{8}$ & $\mathrm{C}_{9}$ & $\mathrm{C}_{10}$ & $\mathrm{C}_{11}$ & $\mathrm{C}_{12}$ & $\Gamma_{0 \mathrm{i}}$ \\
\hline $\mathrm{A}_{1}$ & 0.10 & 0.03 & 0.04 & 0.08 & 0.03 & 0.02 & 0.03 & 0.02 & 0.07 & 0.04 & 0.04 & 0.03 & 0.53 \\
$\mathrm{~A}_{2}$ & 0.05 & 0.10 & 0.07 & 0.04 & 0.09 & 0.03 & 0.03 & 0.04 & 0.02 & 0.06 & 0.02 & 0.03 & 0.58 \\
$\mathrm{~A}_{3}$ & 0.10 & 0.10 & 0.04 & 0.08 & 0.05 & 0.04 & 0.03 & 0.07 & 0.04 & 0.03 & 0.04 & 0.05 & 0.66 \\
$\mathrm{~A}_{4}$ & 0.05 & 0.03 & 0.04 & 0.04 & 0.03 & 0.03 & 0.03 & 0.04 & 0.04 & 0.06 & 0.02 & 0.03 & 0.44 \\
$\mathrm{~A}_{5}$ & 0.10 & 0.03 & 0.07 & 0.04 & 0.03 & 0.04 & 0.09 & 0.04 & 0.07 & 0.06 & 0.07 & 0.05 & 0.69 \\
$\mathrm{~A}_{6}$ & 0.03 & 0.03 & 0.04 & 0.03 & 0.05 & 0.03 & 0.03 & 0.07 & 0.04 & 0.06 & 0.02 & 0.03 & 0.46 \\
$\mathrm{~A}_{7}$ & 0.10 & 0.10 & 0.02 & 0.08 & 0.03 & 0.07 & 0.05 & 0.07 & 0.04 & 0.04 & 0.02 & 0.05 & 0.67 \\
$\mathrm{~A}_{8}$ & 0.05 & 0.10 & 0.02 & 0.08 & 0.05 & 0.03 & 0.05 & 0.07 & 0.04 & 0.10 & 0.04 & 0.09 & 0.71 \\
\hline
\end{tabular}

Finally, overall performance of the alternatives under all criteria are determined according to the grey relational grades like in Table 10. Alternative $\mathbf{A}_{\mathbf{8}}$ with the highest grade of relation is the best alternative. Also in Table 10 the ranking of the alternatives can be seen.

Table 10

Overall performance of alternatives and their rankings

\begin{tabular}{lcccccccc}
\hline Rank & $\mathrm{A}_{8}$ & $\mathrm{~A}_{5}$ & $\mathrm{~A}_{7}$ & $\mathrm{~A}_{3}$ & $\mathrm{~A}_{2}$ & $\mathrm{~A}_{1}$ & $\mathrm{~A}_{6}$ & $\mathrm{~A}_{4}$ \\
\hline$\Gamma_{0 \mathrm{i}}$ & 0.71 & 0.69 & 0.67 & 0.66 & 0.58 & 0.53 & 0.46 & 0.44 \\
\hline
\end{tabular}

\section{Conclusion}

In today's competitive markets, selecting qualified and most appropriate human resources is important for businesses. Some firms use traditional methods based on their intuitions in recruitment process while the others prefers more scientific methods. In this paper, GRA method is proposed for personnel selection to overcome the drawbacks of the traditional methods. In order to show the applicability of this method, it is applied to the personnel selection process of a technology firm. Candidates that apply for software engineer position are evaluated based on twelve decision criteria. These evaluation criteria are determined based on the personality inventory that the firm applies to the candidates. The final ranking of the candidates and the most appropriate one among them is determined with GRA. The ranking of candidates are obtained as $A_{8}>A_{5}>A_{7}>A_{3}>A_{2}>A_{1}>A_{6}>A_{4}$. The best candidate is $A_{8}$ with highest grade of relation and it is advised to the technology firm to hire $A_{8}$ as software engineer. The HR and IT departments found the results of GRA satisfactory and decided to hire $\mathrm{A}_{8}$ candidate.

In this paper GRA method is used because it is very simple and easy to compute and understand. In future studies, other MCDM methods can be used to solve personnel selection problem. Also GRA 
method can be used to solve other MCDM problems of the firms. If the criteria weights are not determined before by the decision makers of the firm, these weights can be determined with AHP (Analytic Hierarch Process) or MACBETH methods.

\section{References}

Afshari, A., Majid, M. \& Rosnah, M.Y. (2010). Simple additive weighting approach to personnel selection problem. International Journal of Innovation, Management and Technology, 1(5), 511-515.

Aksakal, E., Dağdeviren, M., Eraslan, E.,\& Yüksel, İ. (2013). Personel selection based on talent management. Procedia - Social and Behavioral Sciences, 73, 68 - 72.

Alguliyev, R.M., Aliguliyev, R.M., \& Mahmudova, R.S. (2015). Multicriteria personnel selection by the modified fuzzy VIKOR method. The Scientific World Journal, 2015, 1-16.

Baležentis, A., Baležentis, T., \& Brauers, W.K.M. (2012). MULTIMOORA-FG: A multi-objective decision making method for linguistic reasoning with an application to personnel selection. Informatica, 23(2), 173-190.

Birgün, S., \& Güngör, C. (2014). A multi-criteria call center site selection by hierarchy grey relational analysis. Journal of Aeronautics and Space Technologies, 7(1), 45-52.

Boran, F.E., Genç, S., \& Akay, D. (2011). Personnel selection based on intuitionistic fuzzy sets. Human Factors and Ergonomics in Manufacturing \& Service Industries, 21(5), 493-503.

Çaydaş, U., \& Hasçalık, A. (2008). Use of the grey relational analysis to determine optimum laser cutting parameters with multi-performance characteristics. Optics \& Laser Technology, 40(7), 987-994.

Chan, J. W., \& Tong, T. K. (2007). Multi-criteria material selections and end-of-life product strategy: Grey relational analysis approach. Materials \& Design, 28(5), 1539-1546.

Chang, C.L. Tsai, C.H. \& Chen, L. (2003). Applying grey relational analysis to the decathlon evaluation model. International Journal of The Computer, The Internet and Management, 11(3), 54 - 62

Chang, T. C., \& Lin, S. J. (1999). Grey relation analysis of carbon dioxide emissions from industrial production and energy uses in Taiwan. Journal of Environmental Management, 56(4), 247-257.

Chen, C. T. (2000). Extensions of the TOPSIS for group decision-making under fuzzy environment. Fuzzy Sets and Systems, 114(1), 1-9.

Chen, F. L. \& Chen, Y. C. (2010). Evaluating the maintenance performance of the semiconductor factories based on the analytical hierarchy process and grey relational analysis. American Journal of Applied Sciences, 7(4), 568-574.

Chen, L. S., \& Cheng, C. H. (2005). Selecting IS personnel use fuzzy GDSS based on metric distance method. European Journal of Operational Research, 160(3), 803-820.

Chiang, K. T., \& Chang, F. P. (2006). Optimization of the WEDM process of particle-reinforced material with multiple performance characteristics using grey relational analysis. Journal of Materials Processing Technology, 180(1), 96-101.

Chien, C. F., \& Chen, L. F. (2008). Data mining to improve personnel selection and enhance human capital: A case study in high-technology industry. Expert Systems with Applications, 34(1), 280-290.

Dağdeviren, M. (2010). A hybrid multi-criteria decision-making model for personnel selection in manufacturing systems. Journal of Intelligent Manufacturing, 21(4), 451-460.

Das, D., Mishra, P., Chaubey, A., \& Singh, S. (2016). Fabrication process optimization for improved mechanical properties of Al 7075/SiCp metal matrix composites. Management Science Letters, 6(4), 297-308.

Deng, J.L. (1989). Introduction to grey system. The Journal of Grey System, 1(1), 1-24.

Dereli, T., Durmuşoğlu A., Seçkiner S.U. \& Avlanmaz, N. (2010). A fuzzy approach for personnel selection process. Turkish Journal of Fuzzy Systems, 1(2), 126-140.

Dursun, M., \& Karsak, E. E. (2010). A fuzzy MCDM approach for personnel selection. Expert Systems with Applications, 37(6), 4324-4330.

El-Santawy, M.F. (2012). A VIKOR method for solving personnel training selection problem. International Journal of Computing Science, 1(2), 9-12.

Fathi, M.R., Matin, H.Z., Zarchi, M.K., \& Azizollahi, S. (2011). The application of fuzzy TOPSIS approach to personnel selection for Padir Company, Iran. Journal of Management Research, 3(2), 1-14. 
Fung, C. P. (2003). Manufacturing process optimization for wear property of fiber-reinforced polybutylene terephthalate composites with grey relational analysis. Wear, 254(3), 298-306.

Girginer, N., \& Uçkun, N. (2012). The financial performance of the commercial banks in crisis period: evidence from Turkey as an emerging market. European Journal of Business and Management, 4(19), 19-36.

Güngör, Z., Serhadlıŏlu, G., \& Kesen, S. E. (2009). A fuzzy AHP approach to personnel selection problem. Applied Soft Computing, 9(2), 641-646.

Hasani, H., Tabatabaei, S. A., \& Amiri, G. (2012). Grey relational analysis to determine the optimum process parameters for open-end spinning yarns.Journal of Engineered Fibers and Fabrics, 7(2), 81-86.

Hashemi, S. H., Karimi, A., \& Tavana, M. (2015). An integrated green supplier selection approach with analytic network process and improved Grey relational analysis. International Journal of Production Economics, 159, 178-191.

Huang, S. J., Chiu, N. H., \& Chen, L. W. (2008). Integration of the grey relational analysis with genetic algorithm for software effort estimation.European Journal of Operational Research, 188(3), 898-909.

Huang, Y. P., \& Huang, C. C. (1996). The integration and application of fuzzy and grey modeling methods. Fuzzy Sets and Systems, 78(1), 107-119.

Kabak, M. (2013). A Fuzzy DEMATEL-ANP based multi criteria decision making approach for personnel selection. Journal of Multiple-Valued Logic \& Soft Computing, 20(5/6), 571-593.

Kalugina, E., \& Shvydun, S. (2014). An effective personnel selection model, Procedia Computer Science, $31,1102-1106$.

Kao, P. S., \& Hocheng, H. (2003). Optimization of electrochemical polishing of stainless steel by grey relational analysis. Journal of Materials Processing Technology, 140(1), 255-259.

Karsak, E. E. (2001). Personnel selection using a fuzzy MCDM approach based on ideal and anti-ideal solutions, Lecture Notes in Economics and Mathematical Systems, 507, 393-402.

Karsak, E.E. (2000). A fuzzy multiple objective programming approach for personnel selection, 2000 IEEE International Conference on Systems, Man, and Cybernetics, 3 , 2007-2012.

Kelemenis, A., \& Askounis, D. (2010). A new TOPSIS-based multi-criteria approach to personnel selection. Expert Systems with Applications, 37(7), 4999-5008.

Kuo, Y., Yang, T., \& Huang, G. W. (2008). The use of grey relational analysis in solving multiple attribute decision-making problems. Computers \& Industrial Engineering, 55(1), 80-93.

Li, X., Hipel, K. W., \& Dang, Y. (2015). An improved grey relational analysis approach for panel data clustering. Expert Systems with Applications,42(23), 9105-9116.

Liang, G. S., \& Wang, M. J. J. (1994). Personnel selection using fuzzy MCDM algorithm. European Journal of Operational Research, 78(1), 22-33.

Lin, C. L. (2004). Use of the Taguchi method and grey relational analysis to optimize turning operations with multiple performance characteristics.Materials and Manufacturing Processes, 19(2), 209-220.

Lin, H. T. (2010). Personnel selection using analytic network process and fuzzy data envelopment analysis approaches. Computers \& Industrial Engineering, 59(4), 937-944.

Lin, C. L., Lin, J. L., \& Ko, T. C. (2002). Optimisation of the EDM process based on the orthogonal array with fuzzy logic and grey relational analysis method. The International Journal of Advanced Manufacturing Technology,19(4), 271-277.

Liu, H. C., Qin, J. T., Mao, L. X., \& Zhang, Z. Y. (2015). Personnel Selection Using Interval 2-Tuple Linguistic VIKOR Method. Human Factors and Ergonomics in Manufacturing \& Service Industries, 25(3), 370-384.

Lu, I. J., Lin, S. J., \& Lewis, C. (2008). Grey relation analysis of motor vehicular energy consumption in Taiwan. Energy Policy, 36(7), 2556-2561.

Morán, J., Granada, E., Míguez, J. L., \& Porteiro, J. (2006). Use of grey relational analysis to assess and optimize small biomass boilers. Fuel Processing Technology, 87(2), 123-127.

Nasab, F.G. \& Rostamy-Malkhalifeh, M. (2010). Extension of TOPSIS for group decision making based on the type-2 fuzzy positive and negative ideal solutions. International Industrial Mathematics, 2(3), 199-213.

Özçelik, F., \& Öztürk Avc1, B. (2014). Evaluation of banks' sustainability performance in Turkey with grey relational analysis. The Journal of Accounting and Finance, 63, 189-209. 
Pandey, R. K., \& Panda, S. S. (2015). Optimization of multiple quality characteristics in bone drilling using grey relational analysis, Journal of Orthopaedics, 12(1), 39-45.

Rajesh R., \& Ravi, V. (2015). Supplier selection in resilient supply chains: a grey relational analysis approach. Journal of Cleaner Production, 86, 343-359.

Saghafian, S. \& Hejazi S.R. (2005). Multi-criteria group decision making using a modified fuzzy TOPSIS procedure. Proceedings of the 2005 International Conference on Computational Intelligence for Modelling, Control, pp: 215-221.

Sarucan, A. Baysal, E., Kahraman, C. \& Engin, O. (2011). A hierarchy grey relational analysis for selecting the renewable electricity generation technologies, Proceedings of the World Congress on Engineering, Vol II WCE 2011, July 6 - 8, 2011, London, U.K.

Tosun, N. (2006). Determination of optimum parameters for multi-performance characteristics in drilling by using grey relational analysis. The International Journal of Advanced Manufacturing Technology, 28(5-6), 450-455.

Tripathy, S. \& Tripathy D.K. (2016). Multi-attribute optimization of machining process parameters in powder mixed electro-discharge machining using TOPSIS and grey relational analysis. Engineering Science and Technology, an International Journal, 19, 62-70.

Tsai, C.H., Chang,C.L. \& Chen, L. (2003). Applying grey relational analysis to the vendor evaluation model. International Journal of The Computer, The Internet and Management, 11(3), 45 - 53.

Tsao C.T. \& Chu, C.T. (2001). Personnel selection using an improved fuzzy MCDM algorithm. Journal of Information and Optimization Sciences, 22(3), 521-536.

Tseng, M. L. (2010). Using linguistic preferences and grey relational analysis to evaluate the environmental knowledge management capacity. Expert Systems with Applications, 37(1), 70-81.

Tzeng, C. J., Lin, Y. H., Yang, Y. K., \& Jeng, M. C. (2009). Optimization of turning operations with multiple performance characteristics using the Taguchi method and Grey relational analysis. Journal of Materials Processing Technology, 209(6), 2753-2759.

Wang, Z., Lei, T., Chang, X., Shi, X., Xiao, J., Li, Z., ... \& Yang, S. (2015). Optimization of a biomass briquette fuel system based on grey relational analysis and analytic hierarchy process: A study using cornstalks in China.Applied Energy, 157, 523-532.

Wei, G. W. (2011). Grey relational analysis method for 2-tuple linguistic multiple attribute group decision making with incomplete weight information.Expert Systems with Applications, 38(5), 4824-4828.

Wen, K. L. (2004). The grey system analysis and its application in gas breakdown and VAR compensator finding (invited paper). International Journal of Computational Cognition, 2(1), 21-44.

$\mathrm{Wu}$, H.H. (2002). A comparative study of using grey relational analysis in multiple attribute decision making problems. Quality Engineering, 15(2), 209-217.

Xu, G., Yang, Y. P., Lu, S. Y., Li, L., \& Song, X. (2011). Comprehensive evaluation of coal-fired power plants based on grey relational analysis and analytic hierarchy process. Energy Policy, 39(5), 2343-2351.

Yang, C. C., \& Chen, B. S., (2006). Supplier selection using combined analytical hierarchy process and grey relational analysis. Journal of Manufacturing Technology Management, 17(7), 926-941.

Yang, F. Zeng, G. M. Du, C. Tang, L. Zhou J. \& Li, Z., (2009). Integrated geographic information systemsbased suitability evaluation of urban land expansion: A combination of analytic hierarchy process and grey relational analysis. Environmental Engineering Science, 26(6), 1025-1032.

Zeng, G., Jiang, R., Huang, G., Xu, M., \& Li, J. (2007). Optimization of wastewater treatment alternative selection by hierarchy grey relational analysis. Journal of Environmental Management, 82(2), 250-259.

Zhang, S. F., \& Liu, S. Y. (2011). A GRA-based intuitionistic fuzzy multi-criteria group decision making method for personnel selection. Expert Systems with Applications, 38(9), 11401-11405.

Zolfani, S.H., \& Banihashemi, S.S.A. (2014) Personnel selection based on a novel model of game theory and MCDM approaches, $8^{\text {th }}$ International Scientific Conference "Business and Management 2014" May 15-16, Vilnius, Lithuania.

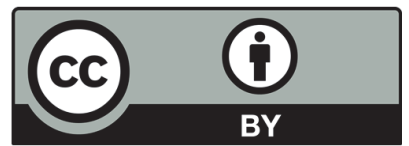

(C) 2016 by the authors; licensee Growing Science, Canada. This is an open access article distributed under the terms and conditions of the Creative Commons Attribution (CC-BY) license (http://creativecommons.org/licenses/by/4.0/). 